\title{
Distribution and changes in urease (EC 3.5.1.5) activity in Rumen Simulation Technique (Rusitec)
}

\author{
BY J. W. CZERKAWSKI AND GRACE BRECKENRIDGE \\ The Hannah Research Institute, Ayr KA6 $5 H L$, Scotland
}

(Received 12 August 1981 - Accepted 4 November 1981)

1. The Rumen Simulation Technique (Rusitec) was used in a series of long-term experiments to study the
distribution and changes of urease ( $E C 3.5 .1 .5$ ) activity in a heterogeneous fermentation system.
2. It was shown that in Rusitec the high urease activity from the inoculum decreased to low values, that the
rate of decrease was consistent with simple dilution of ureolytic micro-organisms and that the urease activity could
be restored to original values by infusion of urea into the reaction vessels. The magnitude of this urease activity
was a direct function of the amounts of urea infused. Single daily additions of the same or greater amounts of
urea in food or as solid failed to increase the urease activity significantly.
3. In general, urease activity increased $2-6$ h after feeding and the increases were greater with roughage diets.
4. The ureolytic activity per unit volume was always higher in compartment 2 (space occupied by micro-organisms
that are loosely associated with the solid) than in compartment 1 (strained rumen contents) or compartment 3
(space occupied by microbial population that cannot be washed out of the solid matrix).
5 . The distribution of urease activity between the compartments was different from the distribution of certain
other enzymes (e.g. protease and alkaline phosphatase (EC 3.1 . 3. 1)).
6 . Apart from the boundary region, the concentrations of urease, ammonia and volatile fatty acids in
compartment 2 were constant, while the concentrations of protein, DNA and another enzyme (alkaline
phosphatase) increased with the depth of the compartment. Specific urease activity (per unit weight of protein
or DNA) was much higher in compartment 1 than in compartment 2 and it decreased markedly with depth of
compartment.
7 . The concentrations of ammonia were always much higher in the solid matrix (compartments 2 and 3 ) than
in the free suspension of micro-organisms (compartment 1 ). There was a linear relation between these two
quantities.

8. The results are discussed in relation to published work on the entry and metabolism of urea in the rumen.

Urea can enter the rumen partly with saliva and partly by diffusion through the rumen wall; in addition, small amounts of urea are incorporated into the diet of domestic ruminants. A sheep may produce 6-16 1 saliva/d and the concentration of urea in saliva may vary from 20 to $360 \mathrm{mg} / \mathrm{l}$, giving an intermittent salivary input of urea ranging from 0.1 to $5.8 \mathrm{~g} / \mathrm{d}$. The estimates of the total entry of urea into the rumen range from values as low as $1 \mathrm{~g} / \mathrm{d}$ to values as high as $27 \mathrm{~g} / \mathrm{d}$ (for review, see Houpt, 1970; Kennedy \& Milligan, 1980). There is a lot of disagreement about the relative proportions of urea entering the rumen by diffusion through rumen wall and with saliva, but the former must be more uniform. When urea is incorporated in food, it will in general enter the sheep rumen rather quickly (at least $30 \mathrm{~g} / \mathrm{h}$ ).

An injection of $10 \mathrm{~g}$ urea (or more) into the rumen caused considerable reduction in the flow of saliva (Obara \& Shimbayashi, 1979) and there was a negative correlation between the flow of saliva and the concentration of ammonia in the rumen and in blood. Since urea is hydrolysed to ammonia in the rumen, an injection of urea would result in increased concentrations of ammonia in the rumen and hence a decreased salivary flow. There is a negative correlation between the over-all transfer of urea into the rumen and the concentration of ammonia in rumen contents, but it is not certain if this is due to reduction in salivary flow (see Kennedy \& Miligan, 1980). It would appear that when roughage is fed to animals, large proportions of urea enter the rumen with saliva and that concentrate diets tend to enhance the transfer of urea across the rumen wall (Kennedy, 1980), but the situation is still confused. 
Urea is hydrolysed to carbon dioxide and ammonia by means of urease (EC 3.5.1.5) and the latter product is used in the synthesis of microbial matter. It was shown by Pearson \& Smith (1943) that urea was subject to microbial degradation in the rumen and since then the subject attracted a great deal of attention and resulted in voluminous literature (see Rahman \& Decker, 1966; Cook 1976; Mahadevan et al. 1976, and reviews by Chalupa, 1968, 1972; Jones, 1967; Tillman \& Sidhu, 1968). There are many ureolytic micro-organisms in the rumen (e.g. Slyter et al. 1968), urease is associated with cells (Brent et al. 1971), but there are difficulties in the identification of ureolytic bacteria. It would seem that a variety of rumen bacteria are collectively responsible for degradation of urea. The enzymes that are concerned with utilization of ammonia for synthesis of amino acids and hence microbial protein have also attracted attention (e.g. Chalupa et al. 1970; Erfle et al. 1977; Wallace, 1979).

Cheng and Wallace (1979) showed that the rumen wall is inhabited by an adherent microbial population and these micro-organisms have considerable ureolytic activity. It has been suggested that the urease associated with these adherent micro-organisms may serve to maintain a localized concentration gradient of urea across the rumen wall and thus increase the rate of diffusion of urea into the rumen. There is considerable urease activity in bulk of rumen contents, and the activity is associated with the cells (Brent et al. 1971).

The Rumen Simulation Technique (Rusitec) is a simple but reliable model system that can be used to study rumen fermentation under controlled conditions (Czerkawski \& Breckenridge, 1977). Rusitec has considerable practical potential (e.g. see Stanier \& Davies, 1981), but it has proved its worth in more fundamental studies and has led directly to the concepts of compartmentation of the rumen and to identification of three compartments (Czerkawski \& Breckenridge, $1979 a, b$; Czerkawski, 1979). The distribution of major groups of micro-organisms (bacteria and protozoa) is different in the three compartments (Czerkawski \& Breckenridge, 1979b) and there are considerable differences in the activities of various enzymes within the compartments (Wallace et al. 1981; Brice \& Morrison, 1981). Alkaline phosphatase $(E C 3.1 .3 .1)$ is associated with the bacterial cell wall (e.g. see Cheng $\&$ Costerton, 1977) and it may act as an indicator of cell lysis (Cheng et al. 1976). In some of the experiments described here, the alkaline phosphatase activity was determined (usually in parallel with urease determinations) mainly because of its known association with the cell wall.

The adherent microbial population of the rumen wall (Cheng \& Wallace, 1979) may form yet another compartment in the rumen, but clearly this compartment is missing in Rusitec. Yet, judged by many criteria, the technique stimulates the rumen function well. The transfer of urea into the rumen and its microbial degradation are subject to complex feed-back mechanisms, which are difficult to control in vivo.

We have observed earlier (Wallace $e t$ al. 1981) that the urease activity in Rusitec decreased to low values and that the infusion of urea into the system caused considerable increase in urease activity. This paper reports a series of experiments with Rusitec, designed to study some of the factors that influence urease activity within the compartments.

EXPERIMEN TA L

\section{Methods and materials}

The incubations were carried out in Rusitec as described by Czerkawski \& Breckenridge (1977). The gases were analysed as described by Czerkawski \& Clapperton (1968) and the volatile fatty acids (VFA) as described by Czerkawski (1976), using pivalic acid as internal standard. The output of microbial matter was determined in terms of diaminopimelic acid (DAP) and aminoethylphosphonic acid (AEP) for bacteria and protozoa respectively (Czerkawski, 1974). The concentration of urea was measured with diacetyl monoxime 
reagent (Sigma Chemical Co., 1980b). The concentrations of carbohydrate were determined by the phenol method (Smith, 1965) and the concentrations of protein by the method of Toennies \& Feng (1965). The DNA was determined as described by Burton (1955). The concentrations of ammonia were determined with the same reagents as used for the urease assays. The protozoal and bacterial counts were made as described by Czerkawski et al. (1975).

The urease activity was determined as production of ammonia as described by Cook (1976, method a), protease activity was determined as degradation of azocasein (Dinsdale $e t$ $a l .1980)$ and alkaline phosphatase $(E C 3.1 .3 .1)$ was measured as release of p-nitrophenol from the phosphate as recommended in Sigma Chemical Co. (1980a). Since this enzyme is inhibited by phosphate, special precautions were taken to keep the phosphate concentrations constant in all the assayed samples (phosphate is present in artificial saliva).

In some experiments, the contents of compartment 2 were fractionated as follows. After draining, the solid digesta in the gauze bags were placed in a larger polyethylene bag and a corner of this was cut off with scissors. The contents were squeezed gently and five to six fractions of 3-5 g liquid were collected. The fractions were weighed and used to determine the concentrations of various substances.

The inocula for incubations were usually obtained from sheep that were kept on the same diet as used in Rusitec.

\section{Experimental outlines}

Expt $l$. The diets used in this experiment were hay (10.39 g dry matter (DM)/d) and a mixed diet of hay and goat mix ( $6 \mathrm{~g}$ of each, $10.38 \mathrm{~g} \mathrm{DM} / \mathrm{d}$ ). The inocula were obtained from sheep given hay or equal proportions of hay and goat mix and each vessel was started with $500 \mathrm{ml}$ liquid rumen contents, $80 \mathrm{~g}$ solid digesta and $250 \mathrm{ml}$ saliva. The $\mathrm{pH}$ value of artificial saliva was 8.5 in vessel 1 (hay) and 9.5 in vessel 2 (concentrate); this maintained the $\mathrm{pH}$ of the reaction mixtures close to $7 \cdot 0$ in both vessels. Apart from the measurements of the output of VFA and gases, the microbial outputs and the digestibility of DM, urease and protease activity were determined at frequent intervals. After the control period of $13 \mathrm{~d}$, urea was infused into both vessels in the artificial saliva $(300 \mathrm{mg} / \mathrm{l})$ until the end of the experiment (days 14-23, $202 \mathrm{mg}$ urea/d).

Expt 2 . In this experiment, vessel 1 was charged daily with $10 \mathrm{~g}$ hay and $5 \mathrm{~g}$ bruised barley and vessel 2 with $5 \mathrm{~g}$ hay and $10 \mathrm{~g}$ bruised barley. Both feeds were supplemented with $0.5 \mathrm{~g}$ soya-bean meal on days $1-41$ and with $0.5 \mathrm{~g}$ casein on days $42-49$. The inoculum for this incubation was obtained from sheep given equal amounts of hay and barley. Apart from the fermentation characteristics (VFA, methane, microbial output), urease and protease activities were measured in all three compartments. Starting with day 8 , increasingly larger amounts of urea were infused into the vessels (nominally $10 \mathrm{mg} / \mathrm{d}$, on days $8-10$, stepping up to 20,40 and $80 \mathrm{mg} / \mathrm{d}$ between days 11 and 20 and a maximum of $160 \mathrm{mg} / \mathrm{d}$ during days 21-27). The urea infusion was lowered to $80 \mathrm{mg} / \mathrm{d}$ on day 28 and continued at that level to the end. The contents of the reaction vessels were perfused with oxygen on days 32-40 (Czerkawski \& Breckenridge, 1979b) to simulate the conditions that may obtain close to the rumen wall (Cheng \& Wallace, 1979).

Expt 3. The inoculum for these two experiments was obtained from sheep given hay and barley ( 800 and $200 \mathrm{~g} / \mathrm{d}$ respectively). The diets used in Rusitec consisted of hay, bruised barley and soya-bean meal, 12, 3 and $1 \mathrm{~g} / \mathrm{d}$ respectively, supplying $13.79 \mathrm{~g} \mathrm{DM} / \mathrm{d}$. The $\mathrm{pH}$ value of the reaction mixtures was kept close to 7.0 by infusion of artificial saliva at $\mathrm{pH}$ 9.5. Expt $3 \mathrm{~b}$ was started approximately 1 month after the end of Expt $3 \mathrm{a}$.

In Expt 3a, urea was dissolved in artificial saliva and infused into vessels 1 and 2 at 30 and $80 \mathrm{mg} / \mathrm{d}$ respectively, during days $9-15$. This was followed by a control period (days 
16-22) when no urea was supplied. During days $23-31$, urea was added with food at 30 and $80 \mathrm{mg} / \mathrm{d}$ in vessels 1 and 2 respectively. To do this, urea was dissolved in aqueous ethanol $(900 \mathrm{ml} / \mathrm{l}), 1.0 \mathrm{ml}$ of this solution was added to food and the solvent was allowed to evaporate before feeding. As in the other experiments, the production of end-products of fermentation was determined daily. The urease and alkaline phosphatase activities were determined in all three compartments (reaction mixture, washings and washed solid). On days $3,11,18,25$ and 31 , the contents of compartment 2 were partly fractionated as described previously.

In Expt $3 b$ the pattern of treatments was as follows. During days 7-13 urea was infused with artificial saliva in vessel $l(96 \mathrm{mg} / \mathrm{d})$, it was added in food as in Expt $3 \mathrm{a}$ in vessel 2 $(100 \mathrm{mg} / \mathrm{d})$ and in vessel 3 the same amount of urea was added as solid at the time of feeding. This treatment period was followed by a control period (days 14-18) and then by another treatment period (days 19-26) in which the treatments in vessels 1 and 2 were reversed (addition in vessel $1,100 \mathrm{mg} / \mathrm{d}$ and infusion in vessel $2,98 \mathrm{mg} / \mathrm{d}$ ). In vessel 3, during days 19-26 urea was added as solid at $200 \mathrm{mg} / \mathrm{d}$. The treatment period of vessel 1 was extended (days 27-31). During that time in addition to the daily inclusion of $100 \mathrm{mg}$ urea in food, urea was infused into the vessel with artificial saliva at $97 \mathrm{mg} / \mathrm{d}$.

In Expt $3 \mathrm{a}$ on the last day the vessels were charged with food as before, but the experiment was terminated $5 \mathrm{~h}$ later. In this way the vessels contained one bag that had been incubated for only $5 \mathrm{~h}$ and another that had been incubated for $29 \mathrm{~h}$. The contents were fractionated and analysed as described previously.

\section{RESULTS}

\section{Expt 1. Increase in urease activity by infusion of urea}

The main object of this experiment was to confirm that urease activity decreased in Rusitec and that it could be increased by infusion of urea, both with the roughage and concentrate diets. The fermentation characteristics indicated that the system was functioning properly and these are reported briefly in Tables 1 and 2 . There were differences in the outputs of VFA and methane on the two diets, but the infusion of urea had little or no effect on these outputs. The infusion of urea caused an increase in microbial output, both in the effluent liquid and in the undigested residue (35-50\% increase when expressed per unit DM digested). As one would expect, urea slightlyincreased the digestibility of hay but not the hay-concentrate diet. The concentrations of protozoa and bacteria were in general greater on the concentrate than on hay (Table 2), both in free suspension (compartment 1) and in the samples washed from solid digesta (compartment 2). Urea had little or no effect on microbial concentrations, particularly in compartment 1 . In agreement with our earlier observations (Czerkawski \& Breckenridge, $1979 a$ ) the microbial concentrations were considerably greater in compartment 2 than in compartment 1 (particularly protozoal concentrations on hay diet).

The urease activity in compartment 1 declined in both vessels approximately with the same rate as the dilution rate (Fig. $1 a$ ). In an experiment with three different concentrates (not reported here), the decline in urease activity in compartment 1 was exponential with the mean rate constant $1.27,1.15$ and $1.22 / \mathrm{d}$ with barley, maize and oats respectively, while the mean dilution rate in that compartment was $1 \cdot 12 / \mathrm{d}$. The urease activity remained low and then increased rapidly when urea was infused. The urease activity increased after feeding and then declined, particularly with hay diet, but the prefeed values were higher than in the absence of urea (days 2-13). The changes in the prefeed urease activities in compartments 2 and 3 are shown in Fig. $1 b$. The urease activity in the washed solid (compartment 3 ) was variable as one would expect from determinations in a heterogeneous system but was not very different from the activity in compartment 1 . It took longer to produce a steady pattern of increased urease activity in compartments 2 and 3 than in compartment 1. Expressed 
Table 1. Expt 1. Outputs of methane, volatile fatty acids (VFA) and microbial matter during incubation of hay and hay-concentrate in Rumen Simulation Technique (Rusitec)

(The results are mean values with their standard error of five determinations on separate days or duplicate determinations on bulked samples)

\begin{tabular}{|c|c|c|c|c|c|c|}
\hline \multirow[b]{2}{*}{$\begin{array}{l}\text { Treatment... } \\
\text { Period (d)... }\end{array}$} & \multicolumn{3}{|c|}{ Vessel 1 (hay) } & \multicolumn{3}{|c|}{ Vessel 2 (hay-concentrate) } \\
\hline & $\begin{array}{c}\text { Control } \\
8-13\end{array}$ & $\begin{array}{c}\text { Urea } \\
15-23\end{array}$ & SE & $\begin{array}{c}\text { Control } \\
8-13\end{array}$ & $\begin{array}{c}\text { Urea } \\
15-23\end{array}$ & SE \\
\hline DM digested $(\mathrm{g} / \mathrm{d})$ & $5 \cdot 43$ & $5 \cdot 70$ & $0 \cdot 07$ & $6 \cdot 33$ & $6 \cdot 17$ & 0.06 \\
\hline Methane (mmol/d) & $11 \cdot 50$ & $10 \cdot 80$ & 0.5 & $8 \cdot 64$ & $8 \cdot 66$ & $0 \cdot 3$ \\
\hline \multicolumn{7}{|l|}{$\mathrm{VFA}(\mathrm{mmol} / \mathrm{d})$} \\
\hline Acetic & $28 \cdot 6$ & $28 \cdot 0$ & 0.6 & $28 \cdot 8$ & $26 \cdot 7$ & 0.5 \\
\hline Propionic & 8.6 & $8 \cdot 3$ & $0 \cdot 1$ & $13 \cdot 6$ & $11 \cdot 5$ & 0.2 \\
\hline Butyric & $4 \cdot 2$ & $4 \cdot 2$ & $0 \cdot 2$ & $6 \cdot 3$ & 5.9 & 0.2 \\
\hline $\mathrm{C}_{5}$-acids & 0.2 & 0.0 & $0 \cdot 2$ & 1.7 & 1.4 & 0.4 \\
\hline Total & $41 \cdot 6$ & $40 \cdot 5$ & - & $50 \cdot 4$ & $45 \cdot 5$ & - \\
\hline \multicolumn{7}{|l|}{ Microbial DM (g/d) } \\
\hline Effluent & 0.23 & 0.37 & - & 0.62 & 0.75 & - \\
\hline Residue & 0.33 & 0.52 & - & 0.23 & 0.37 & - \\
\hline Total & 0.56 & 0.89 & - & 0.85 & $1 \cdot 12$ & - \\
\hline \multicolumn{7}{|l|}{ Output per unit } \\
\hline \multicolumn{7}{|l|}{ DM digested } \\
\hline Methane (mol/kg) & $2 \cdot 12$ & 1.89 & - & $1 \cdot 27$ & $1 \cdot 40$ & - \\
\hline VFA $(\mathrm{mol} / \mathrm{kg})$ & 7.66 & $7 \cdot 11$ & - & 7.96 & $7 \cdot 37$ & - \\
\hline Microbial DM $(\mathrm{g} / \mathrm{kg})$ & 103 & 156 & - & 134 & 182 & - \\
\hline
\end{tabular}

DM, dry matter.

Table 2. Expt 1. Microbial concentration in compartments 1 and 2 (in Rusitec) during control period (days 8-13) and during addition of urea (days 14-23), using hay and hay-concentrate diet

(Each result is the mean of four to five determinations. Proportion of holotrichs in parentheses $(\%$ total protozoa)

\begin{tabular}{|c|c|c|c|c|c|c|}
\hline \multirow[b]{2}{*}{ Treatment ... } & \multicolumn{3}{|c|}{ Vessel 1 (hay) } & \multicolumn{3}{|c|}{ Vessel 2 (hay-concentrate) } \\
\hline & Control & Urea & SE & Control & Urea & SE \\
\hline \multicolumn{7}{|l|}{$\begin{array}{l}\text { Protozoa } \\
\left(\times 10^{4} / \mathrm{ml}\right)\end{array}$} \\
\hline Compartment $1^{*}$ & $1+1(70)$ & $0.8(65)$ & $0 \cdot 1$ & $5 \cdot 5(5)$ & $5 \cdot 1(3)$ & 0.6 \\
\hline Compartment $2 \dagger$ & $42 \cdot 2(50)$ & $28 \cdot 0(48)$ & 3.7 & $44 \cdot 7(6)$ & $54 \cdot 8(5)$ & $9 \cdot 4$ \\
\hline $2: 1$ & 38 & 35 & - & 8 & 11 & - \\
\hline \multicolumn{7}{|l|}{$\begin{array}{l}\text { Bacteria } \\
\left(\times 10^{10} / \mathrm{ml}\right)\end{array}$} \\
\hline Compartment 1 & $10 \cdot 2$ & $10 \cdot 6$ & 1.4 & $12 \cdot 1$ & $10 \cdot 9$ & $1 \cdot 0$ \\
\hline Compartment 2 & $26 \cdot 3$ & $33 \cdot 9$ & $2 \cdot 7$ & $34 \cdot 1$ & $39 \cdot 7$ & $2 \cdot 7$ \\
\hline $2: 1$ & $2 \cdot 6$ & $3 \cdot 4$ & - & $2 \cdot 8$ & $3 \cdot 6$ & - \\
\hline
\end{tabular}

* Free suspension of micro-organisms.

$\dagger$ Concentration in washing corrected for dilution (i.e. concentration in washings $\times$ (volume of washings)/ (volume of compartment 2)). 




Fig. 1. Expt 1. Urease (EC 3 .5 .1 .5) activity ( $\mu$ gammonia-N/ml per $\mathrm{min}$ ) in Rusitec during incubation of hay $(O \triangle \square)$ and hay-concentrate $(\triangle \Delta \square)$; (a) effect of infusion of urea $(202 \mathrm{mg} / \mathrm{d})$ on urease activity in compartment $1(\mathrm{O}, \mathbf{O}),(b)$ effect of infusion of urea in compartment $2(\Delta, \Delta)$ and compartment $3(\square, \square)$ in pre-feed samples.

per unit volume the urease activity in compartment 2 was markedly higher than in the other two compartments, particularly with the hay diet, but the microbial concentrations were much greater in compartment 2 than in compartment 1 (see Table 3). Whereas the infusion of urea increased urease several-fold, particularly in compartment 2 , the increase in protease activity was lower (approximately $60 \%$ ). Protease activity was much greater in compartment 2 than in compartment 1 (14-20 fold) compared with urease activity (3-4 fold).

\section{Expt 2. Effect of infusion of increasing amounts of urea}

Having demonstrated that the urease activity in Rusitec could be increased by infusion of urea, the next objective was to find the minimal concentration of urea in the artificial saliva to trigger this increase and to see if there was a relation between the rate of input and the magnitude of the urease activity.

As in Expt 1 (hay-concentrate diet) the infusion of progressively larger amounts of urea had little or no effect on the production of methane and VFA and the digestibility of the basal rations (Table 4). As expected, the outputs of methane and VFA and the digestibility of DM were significantly greater in vessel 2 than in vessel 1 (greater proportion of barley). When expressed per unit DM digested, methane production was slightly greater in vessel 1 (roughage) and the proportions of propionic acid were greater with higher input of urea, 
Table 3. Expt 1. Urease (EC 3.5.1.5) activity ( $\mu \mathrm{g}$ ammonia-N/ml per min) and protease activity (arbitrary units ${ }^{*} / \mathrm{ml}$ ) in Rusitec during control period (days 3-13) and during infusion of urea (days 16-23)

(Mean values with their standard errors (only the prefeed samples are given))

\begin{tabular}{|c|c|c|c|c|c|c|c|c|c|}
\hline \multirow{3}{*}{$\begin{array}{c}\text { Compartment } \\
\text { no. }\end{array}$} & \multirow{3}{*}{$\begin{array}{l}\text { Period of } \\
\text { experiment } \\
\text { (d) }\end{array}$} & \multicolumn{4}{|c|}{ Vessel 1 (hay) } & \multicolumn{4}{|c|}{ Vessel 2 (hay-concentrate) } \\
\hline & & \multicolumn{2}{|c|}{ Urease } & \multicolumn{2}{|c|}{ Protease } & \multicolumn{2}{|c|}{ Urease } & \multicolumn{2}{|c|}{ Protease } \\
\hline & & Mean & SE & Mean & SE & Mean & SE & Mean & SE \\
\hline \multirow[t]{2}{*}{1} & $3-13$ & 0.4 & $0 \cdot 1$ & 5 & 1 & 0.7 & $0 \cdot 3$ & 5 & 1 \\
\hline & $16-23$ & $3 \cdot 3$ & $0 \cdot 2$ & 8 & 1 & $3 \cdot 2$ & $0 \cdot 3$ & 9 & 3 \\
\hline \multirow[t]{2}{*}{2} & $3-13$ & $1 \cdot 6$ & $0 \cdot 3$ & 71 & 3 & $1 \cdot 8$ & $0 \cdot 4$ & 104 & 8 \\
\hline & $16-23$ & $16 \cdot 6$ & $2 \cdot 0$ & 108 & 16 & $13 \cdot 2$ & $3 \cdot 1$ & 161 & 18 \\
\hline \multirow[t]{2}{*}{3} & $3-13$ & 1.8 & $0 \cdot 3$ & - & - & $1 \cdot 2$ & $0 \cdot 2$ & - & - \\
\hline & $16-23$ & $5 \cdot 5$ & $1 \cdot 0$ & $\ldots$ & - & 3.7 & 1.9 & - & - \\
\hline
\end{tabular}

* Increase in optical density at $450 \mathrm{~nm} / \mathrm{h} \times 1000$.

Table 4. Expt 2. Effect of infusion of increasing amounts of urea on the output of methane, volatile fatty acids (VFA), the digestibility of dry matter (DM) and the output of microbial matter during incubation of hay-barley rations in Rusitec

(Each result is a group mean of values for four periods with low urea input $(\mathrm{L}, 0-42 \mathrm{mg} / \mathrm{d}$ ) and high urea input $(\mathrm{H}, 85-110 \mathrm{mg} / \mathrm{d}))$

\begin{tabular}{|c|c|c|c|c|c|c|}
\hline \multirow[b]{2}{*}{ Period of experiment (d) ... } & \multicolumn{2}{|c|}{$\begin{array}{c}\text { Vessel } 1 \\
\text { (hay-barley } 10: 5, \mathrm{w} / \mathrm{w})\end{array}$} & \multirow[t]{2}{*}{ SE } & \multicolumn{2}{|c|}{$\begin{array}{c}\text { Vessel } 2 \\
\text { (hay-barley } 5: 10, w / w)\end{array}$} & \multirow[t]{2}{*}{ SE } \\
\hline & ${ }_{L}^{4-16}$ & $\begin{array}{c}17-40 \\
\mathrm{H}\end{array}$ & & ${ }_{\mathrm{L}}^{4-16}$ & $\begin{array}{c}17-40 \\
H\end{array}$ & \\
\hline Methane (mmol/d) & $9 \cdot 3$ & $9 \cdot 3$ & 0.3 & $12 \cdot 6$ & $11 \cdot 0$ & 0.6 \\
\hline VFA $(\mathrm{mmol} / \mathrm{d})$ & $48 \cdot 3$ & $48 \cdot 8$ & 0.7 & $66 \cdot 3$ & 66.9 & 0.9 \\
\hline Digestibility (g/kg) & 484 & 486 & 4 & 659 & 655 & 2 \\
\hline \multicolumn{7}{|l|}{ Microbial output $(\mathrm{g} / \mathrm{d})$} \\
\hline Effluent & $0 \cdot 60$ & 0.54 & 0.02 & 0.75 & 0.75 & 0.02 \\
\hline Residue & 0.43 & 0.53 & 0.03 & $0 \cdot 27$ & 0.34 & 0.01 \\
\hline Total & 1.03 & $1 \cdot 07$ & - & $1 \cdot 02$ & 1.09 & - \\
\hline
\end{tabular}

particularly when the proportion of barley in the diet was increased. The infusion of urea in this experiment had only a small effect on the output of microbial matter. This was probably due to greater proportion of readily fermented carbohydrate and protein in diets containing barley as well as soya-bean meal. As in Expt 1 , the infusion of increasing amounts of urea had little effect on microbial concentrations and again these were much higher in compartment 2 than in compartment 1 . In general the proportions of holotrich protozoa were greater in compartment 2 .

The determination of urease and protease activity in this experiment (Table 5) confirmed that per unit volume the urease activity was greatest in compartment 2 . Again the relative distribution of urease and protease was different in the compartments. The protease was also determined (with some difficulty) in compartment 3 , it appeared to be similar to the activity in compartment 2 . There was a small, but consistent increase in proteolytic activity with increasing rates of infusion of urea.

In general, urease activity increased with the concentration of urea in the artificial saliva 
Table 5. Expt 2. Effect of infusion of urea on urease (EC 3.5.1.5) and protease activity in compartments 1,2 and 3 in Rusitec

(The results are means of four to five values, each being the mean of three to four determinations on different days. The mean concentrations of protein in compartments 1,2 and 3 were $0.8,15.6$ and $125.5 \mathrm{mg} / \mathrm{ml}$ and $1.0,21 \cdot 0$ and $139.0 \mathrm{mg} / \mathrm{ml}$ in vessel 1 and 2 respectively)

\begin{tabular}{|c|c|c|c|c|c|c|}
\hline \multirow{2}{*}{$\begin{array}{l}\text { Hay-barley... } \\
\text { Urea }(\mathrm{mg} / \mathrm{d}) . .\end{array}$} & \multicolumn{3}{|c|}{$\begin{array}{c}\text { Vessel 1 } \\
(10: 5 \mathrm{w} / \mathrm{w})\end{array}$} & \multicolumn{3}{|c|}{$\begin{array}{c}\text { Vessel } 2 \\
(5: 10 \mathrm{w} / \mathrm{w})\end{array}$} \\
\hline & 042 & $85-170$ & SE & $0-42$ & $85-170$ & $\mathrm{SE}$ \\
\hline \multicolumn{7}{|c|}{ Urease ( $\mu \mathrm{g}$ ammonia $\mathrm{N} / \mathrm{ml}$ per min) } \\
\hline 1 & 0.53 & $1 \cdot 34$ & 0.08 & 0.78 & $2 \cdot 72$ & 0.34 \\
\hline 2 & $3 \cdot 53$ & $9 \cdot 20$ & $1 \cdot 34$ & $2 \cdot 41$ & $6 \cdot 80$ & 0.83 \\
\hline 3 & 1.91 & $3 \cdot 20$ & 0.50 & 1.44 & $2 \cdot 83$ & 0.30 \\
\hline \multicolumn{7}{|c|}{ Protease (arbitrary units $* / \mathrm{ml}$ ) } \\
\hline 1 & $4 \cdot 3$ & 4.7 & 0.8 & $9 \cdot 3$ & $10 \cdot 4$ & 0.7 \\
\hline 2 & $120 \cdot 5$ & $169 \cdot 2$ & $8 \cdot 3$ & 185.0 & $223 \cdot 0$ & 13.4 \\
\hline 3 & $110 \cdot 0$ & $121 \cdot 2$ & $19 \cdot 0$ & $98 \cdot 8$ & $124 \cdot 2$ & $10 \cdot 4$ \\
\hline \multicolumn{7}{|c|}{ (Urease: protease $\times 1000)$} \\
\hline Compartment & & & & & & \\
\hline 1 & $13 \cdot 3$ & $28 \cdot 5$ & - & $8 \cdot 4$ & & 一 \\
\hline 2 & $2 \cdot 9$ & $5 \cdot 4$ & - & $1 \cdot 3$ & $3 \cdot 0$ & 一 \\
\hline 3 & $1 \cdot 1$ & $2 \cdot 6$ & - & 1.4 & $2 \cdot 3$ & - \\
\hline
\end{tabular}

* Increase in optical density at $450 \mathrm{~nm} / \mathrm{h} \times 1000$.

and the results are summarized in Fig. 2. The amounts of urea required to increase urease activity in compartment 2 were not the same on the same rations. With the roughage diet (2 parts hay, 1 part barley), urease activity increased even with $10 \mathrm{mg}$ urea/d (Fig. 2), whereas with the concentrate diet (1 part hay, 2 parts barley) the urease activity did not increase properly until the rate of infusion was greater than $40 \mathrm{mg} / \mathrm{d}$ (Fig. $2 a$ ). In compartments 1 and 3 on both rations the urease activity began to increase when the rate of infusion was greater than $40 \mathrm{mg} / \mathrm{d}$. In most instances, once triggered, urease activity increased with the amount of urea added $(85-170 \mathrm{mg} / \mathrm{d})$ and decreased when the amount of urea was decreased (from 170 to $85 \mathrm{mg} / \mathrm{d}$ after day 28 ). The values for $85 \mathrm{mg} / \mathrm{d}$ of urea in Fig. 2 $(a$ and $b$ ) are the means for 4 periods, one before the $170 \mathrm{mg} / \mathrm{d}$ level and three after that level, and include periods in which soya-bean meal was replaced by casein and a period of perfusion with oxygen. Neither treatment had any marked effect on urease activity.

\section{Expt 3. Comparison of infusion and single daily addition of urea}

Expt 2 and other experiments not reported here, showed that the increase in urease activity was a direct function of the concentration of urea in the artifical saliva. It was reasonable to suppose that a single addition of urea would result in a large increase in the concentration of urea in the vessel and that this would rapidly 'trigger off' an increase in urease activity. Thus, Expt 3 was largely designed to investigate the effects of the mode of administration of urea on urease activity. However, since earlier exploratory results showed that some substances were evenly distributed in compartment 2 , while others were not, this aspect was investigated at the same time.

The supplementation of the basal rations with urea $(30-200 \mathrm{mg} / \mathrm{d})$ either by infusion with saliva or by direct addition with food, had no effect on the digestibility of DM, 


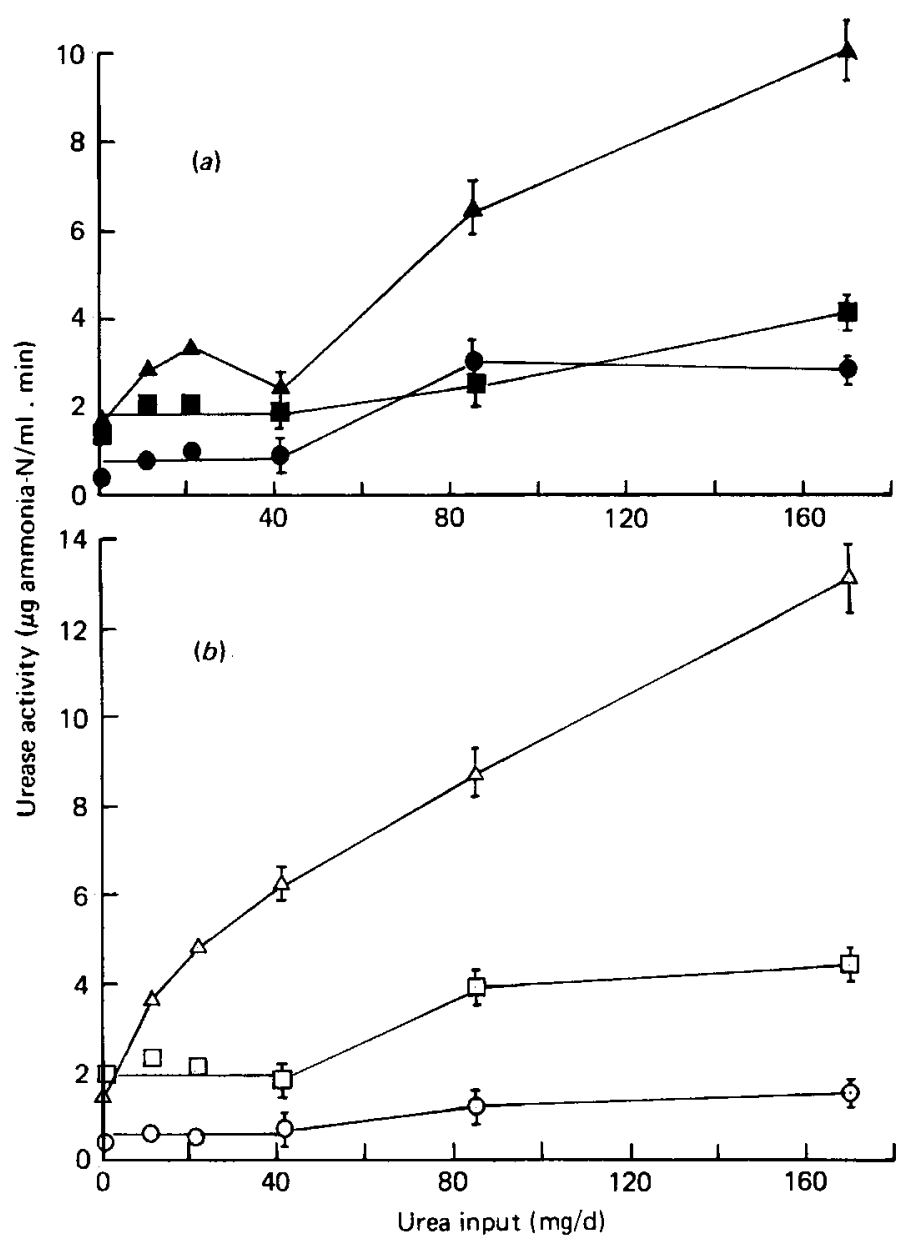

Fig. 2. Expt 2. Effect of infusion of urea on urease (EC 3.5.1.5) activity ( $\mu \mathrm{g}$ ammonia- $\mathrm{N} / \mathrm{ml}$ per min) in Rusitec in compartments $1(O, O), 2(\triangle, \Delta)$ and $3(\square, \square)$; with $(a)$ concentrate diet (1 part hay, 2 parts barley) and $(b)$ roughage diet ( 2 parts hay, 1 part barley).

production of VFA and methane or the output of microbial matter. The mean production of methane and VFA during the ten control periods was $1.75 \pm 0.05$ and $7.54 \pm 0.10 \mathrm{~mol} / \mathrm{kg}$ DM digested respectively. During infusion of urea (four periods) and addition of urea (six periods) the outputs of methane and VFA were $1 \cdot 72 \pm 0.07,7 \cdot 44 \pm 0 \cdot 14$ and $1 \cdot 75 \pm 0.06$, $7 \cdot 34 \pm 0 \cdot 13 \mathrm{~mol} / \mathrm{kg}$ DM digested respectively. There was no difference between the results in Expts $3 a$ and $3 b$, although they were quite separate experiments.

The calculations of hydrogen balance (Marty \& Demeyer, 1973; Czerkawski \& Breckenridge, $1979 b$ ) showed that the mean recovery of hydrogen was $98.3 \pm 1.3 \%$ during the ten control periods, $99.5 \pm 0.9 \%$ during four periods of infusion of urea and $98.2 \pm 0.7 \%$ during the six periods of addition of urea with food. The hydrogen balance was good in Expt 2 (97\% recovery), but the recovery was somewhat lower in Expt 1 (91-93\%). The administration of urea had no effect on the hydrogen recovery.

The results of determinations of urease activity in these experiments are summarized in Table 6 . In general, urease activity was higher $2-6 \mathrm{~h}$ after feeding than before feeding and it was higher in compartment 2 than in compartments 1 and 3 . These results agreed with 
Table 6. Expts $3 a$ and $3 b$. Summary of urease (EC 3.5.1.5) activity in Expts $3 a$ and $b$ ( $\mu \mathrm{g}$ ammonia- $\mathrm{N} / \mathrm{ml}$ per $\mathrm{min}$ )

(All values were corrected for small apparent urease activity with inactivated samples. The concentrations of ammonia in compartment 1 (mg ammonia-N/l) are also given. The results are means for the periods)

\begin{tabular}{|c|c|c|c|c|c|c|}
\hline \multirow[t]{2}{*}{ No. of periods... } & \multicolumn{2}{|c|}{$\begin{array}{c}\text { Controls } \\
10\end{array}$} & \multicolumn{2}{|c|}{$\begin{array}{l}\text { Infusions of urea } \\
(30-100 \mathrm{mg} / \mathrm{d}) \\
3\end{array}$} & \multicolumn{2}{|c|}{$\begin{array}{l}\text { Additions of urea } \\
(30-200 \mathrm{mg} / \mathrm{d}) \\
6\end{array}$} \\
\hline & Mean & $\mathbf{S E}$ & Mean & SE & Mean & $\mathbf{S E}$ \\
\hline \multicolumn{7}{|l|}{ Urease } \\
\hline \multicolumn{7}{|l|}{ Compartment 1} \\
\hline Before feed & $0 \cdot 32$ & 0.06 & 2.73 & 0.43 & 0.19 & 0.03 \\
\hline $2-6 \mathrm{~h}$ after feed & 0.40 & 0.09 & $3 \cdot 50$ & 0.53 & 0.64 & 0.05 \\
\hline \multicolumn{7}{|l|}{ Compartment 2} \\
\hline Before feed & $1 \cdot 31$ & $0 \cdot 20$ & $3 \cdot 58$ & 0.43 & 1.66 & $0 \cdot 17$ \\
\hline \multicolumn{7}{|l|}{ Compartment 3} \\
\hline Before feed & $1 \cdot 07$ & $0 \cdot 38$ & $3 \cdot 16$ & 0.51 & 1.26 & $0 \cdot 50$ \\
\hline \multicolumn{7}{|l|}{ Ammonia concentration } \\
\hline Before feed & 123 & 3 & 168 & 8 & 155 & 7 \\
\hline $2-6 h$ after feed & 160 & 7 & 199 & 7 & 217 & 14 \\
\hline
\end{tabular}

those in Expts 1 and 2 and although the means for all infusion periods are given in Table 6 , the actual values showed an increase with the concentration of urea in the artificial saliva. For instance, the urease activity in the prefeed samples of compartment 1 during infusion of 30,80 and $100 \mathrm{mg}$ urea/d were $1 \cdot 9,3 \cdot 2$ and $4 \cdot 1 \mu \mathrm{g}$ ammonia- $\mathrm{N} / \mathrm{ml}$ per min, respectively.

When the same or greater amounts of urea were added in food or with food there was no marked increase in urease activity. In these experiments attempts were made to ascertain that the low activities were not negligible, by parallel incubations of samples that had been heated for $10 \mathrm{~min}$ at $100^{\circ}$. The inactivated samples gave a small apparent urease activity, but they showed that the low values obtained during the periods of addition of urea and during control periods could not be ignored. The failure of single daily additions of urea to increase urease activity was investigated further by determining the concentrations of urea in the reaction vessels after addition of urea.

First, in parallel, non-fermentation tests, the introduction of a bag of food in which $100 \mathrm{mg}$ urea was incorporated, into a reaction vessel filled with artificial saliva only, resulted in a complete solubilization of the added urea within $15 \mathrm{~min}$ of addition. Therefore, it was concluded that urea became evenly distributed within the vessels soon after addition and that it was readily available to micro-organisms. Next, the concentrations of urea were determined in the experimental vessels. During control periods and during infusion of urea, the colorimetric determinations of urea showed slight increase 1-2 $\mathrm{h}$ after feeding and then a decrease. When urea was added in food or directly as solid the concentrations of urea were high initially and then they decreased. There were two distinct phases of disappearance of urea from compartment 1 , a slower rate up to $1.5 \mathrm{~h}$ after feeding and a faster rate 1.5 to $4 \mathrm{~h}$ after feeding. Virtually all urea disappeared $5 \mathrm{~h}$ after addition. The disappearance of urea was exponential and the mean specific rates of disappearance were $0.41 \pm 0.09$ and $0.74 \pm 0 \cdot 20 / \mathrm{h}$ during the slow and fast phase respectively (4 determinations). The mean dilution rate in this experiment was approximately $0.05 / \mathrm{h}$ and therefore urea was being removed eight times faster than by simple dilution up to $1.5 \mathrm{~h}$ of incubation and fifteen times faster after that time. Extrapolation of the logarithmic plots of urea concentrations 
in the first phase to zero time gave values of 116 and $224 \mathrm{mg} / \mathrm{l}$ after addition of 100 and $200 \mathrm{mg}$ urea. Since the volume of each vessel was $850 \mathrm{ml}$, the recovery of added urea was complete $(98 \%)$. The determinations of the concentrations of urea in compartments 2 and 3 at the end of the day showed that urea did not accumulate in that part of the system.

It was possible to calculate the effective urease activity from the rates of disappearance of urea, when the latter were corrected for dilution. The mean value between 1 and $2 \mathrm{~h}$ of incubation was $0.24 \mu \mathrm{g} \mathrm{NH} / \mathrm{N} / \mathrm{ml}$ per min, while the measured urease activity (in the presence of excess substrate in the assay) was approximately $1.0 \mu \mathrm{g}$ ammonia $\mathrm{N} / \mathrm{ml}$ per min. Allowing for the fact that the rate of reaction within the vessel was not maximum, it would appear that the low urease activity measured during periods of addition of urea may be sufficient to hydrolyse the substrate. This was supported by the results of measurements of the concentrations of ammonia in compartment 1 (see Table 6). This concentration increased whether urea was infused or added at the start of incubation.

\section{Concentration of urease and alkaline phosphatase in compartment 2}

On selected days in some experiments, after allowing to drain, the bags of solid digesta were squeezed and a number of fractions were collected. The results of determinations of urease and alkaline phosphatase activities on the last day of infusion of urea in Experiment $3 \mathrm{a}$ are given in Fig. 3. Clearly, the urease activity declined slowly and the alkaline phosphatase activity increased markedly with the 'depth' of compartment 2 . When these determinations were made at the end of control periods or at the end of addition of urea, urease activity was low and did not change much while alkaline phosphatase increased as before (Fig. 4). When urea was infused (results from Expt $3 \mathrm{~b}$ ) similar results were obtained (urease activity showed little or no change and alkaline phosphatase activity increased 2-3 fold between the first and last fractions).

In addition to the previously mentioned two enzymes, the concentrations of other substances were determined in the fractions of compartment 2 . It was found that the concentrations of ammonia did not change appreciably. For example, in vessel 2 (Expt $3 \mathrm{a}$ ), when urea was infused the mean concentration of ammonia- $N$ was $368 \pm 12 \mathrm{mg} / 1$, while for control period in the same vessel the concentration was $214 \pm 13 \mathrm{mg} / \mathrm{l}$. The lack of change in ammonia concentration was consistent with the small change in urease activity in the fractions.

The determination of the concentration of protein, DNA and total carbohydrate in fractions showed that all these quantities increased with the depth of compartment 2. Moreover, the DNA:protein value in these fractions was constant $(24.6 \pm 0.7$ and $38.0 \pm 0.4 \mathrm{mg} / \mathrm{g}$ after 48 and $24 \mathrm{~h}$ of incubation respectively). Since DNA can be taken as an approximate measure of microbial matter and since the DNA:protein value was constant for a given time of incubation, it may be possible to express enzyme activities in a more specific manner (per unit weight of protein). It can be seen in Table 7 that, whereas the specific urease activity decreased considerably with depth of compartment 2 , specific alkaline phosphatase activity remained practically unchanged. When the enzyme activities in compartment 1 were expressed in the same way (per unit weight of protein) the differences in the distribution of these two enzymes were also striking.

The alkaline phosphatase activity in compartment 1 was not markedly greater than in compartment $2(0.50$ compared with the highest value of $0.35 \mu \mathrm{mol} / \mathrm{h}$ per $\mathrm{mg})$. The specific urease activity in compartment 1 was 4.8 and $0.8 \mu \mathrm{g}$ ammonia- $\mathrm{N} / \mathrm{min}$ per $\mathrm{mg}$ during infusion and addition of urea respectively. Thus, the specific urease activity in compartment 1 was six to ten times greater than the highest activity in compartment 2.

It is difficult to obtain meaningful values of protein content in the washed solid residue 


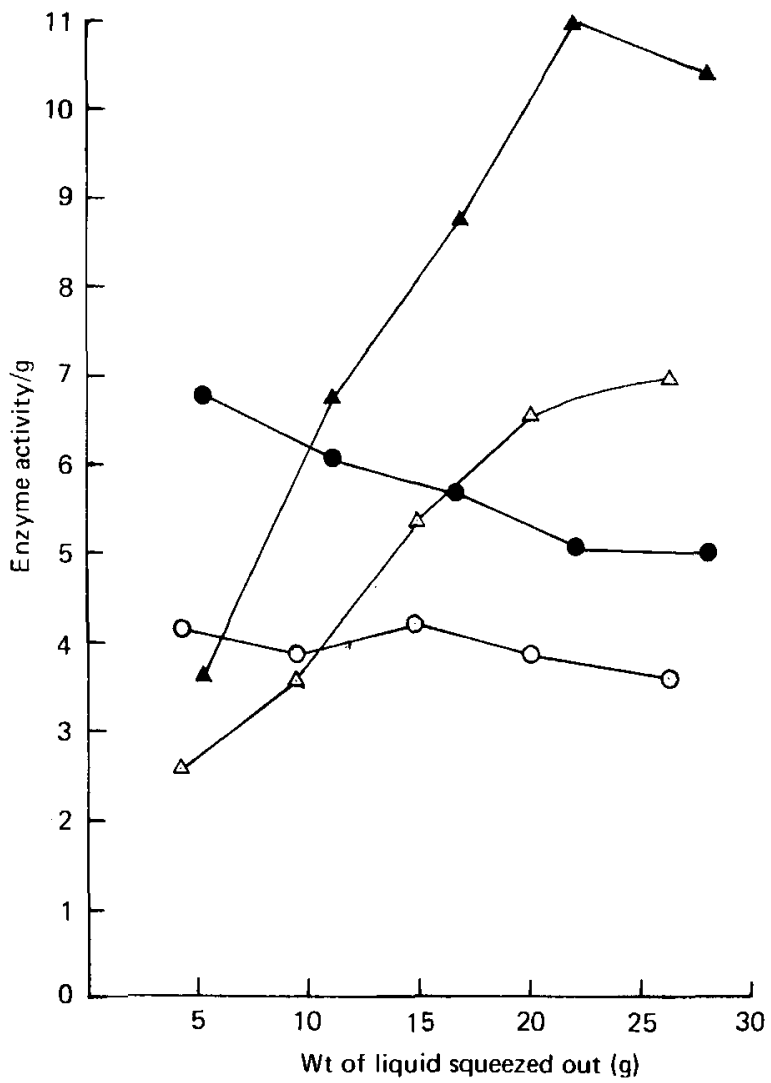

Fig. 3. Expt 3a. Changes in urease (EC 3.5.1.5; $\mu \mathrm{g}$ ammonia-N/min) and alkaline phosphatase (EC $3.1 .3 .1 ; \mu \mathrm{mol} / \mathrm{h})$ activity in the fractions squeezed out of the bags of solid digesta during the infusion of urea. Urease $(0,0)$ alkaline phosphatase $(\Delta, \Delta) ; 0, \triangle$, vessel $1 ; 0, \Delta$, vessel 2 .

(compartment 3), since a great deal of the estimated protein may be non-microbial. A better reference substance may be the bacterial marker DAP. Some of the specific activities of urease and alkaline phosphatase, expressed in terms of DAP are given in Table 8. The infusion of urea gave generally higher urease activity, while the mode of administration had little or no effect on the alkaline phosphatase activity. On the average, the specific urease activity in compartment 1 was ten times greater than in compartments 2 and 3 , while the specific alkaline phosphatase was at most twice as great in compartment 1 as in the other two compartments. This is consistent with wide distribution of alkaline phosphatase within cells and suggests that urease may be primarily associated with the microbial population of compartment 1 .

\section{Other observations}

The experiments resulted in numerous observations which cannot be given here in detail and which will form part of a separate study. For instance, when the contents of the bags were fractionated after 5 and $29 \mathrm{~h}$ of incubation, rather than the usual $48 \mathrm{~h}$, alkaline phosphatase per unit weight protein was not constant, but increased at 5.3 and $3.4 \%$ of the initial value per $\mathrm{g}$ fraction respectively. Irrespective of the time of incubation the specific activity of urease decreased $(2.4 \% / \mathrm{g}$ fraction). The specific activity of various glycosidases (R. Brice, private communication) increased with the depth of compartment 2 even after long incubation. 


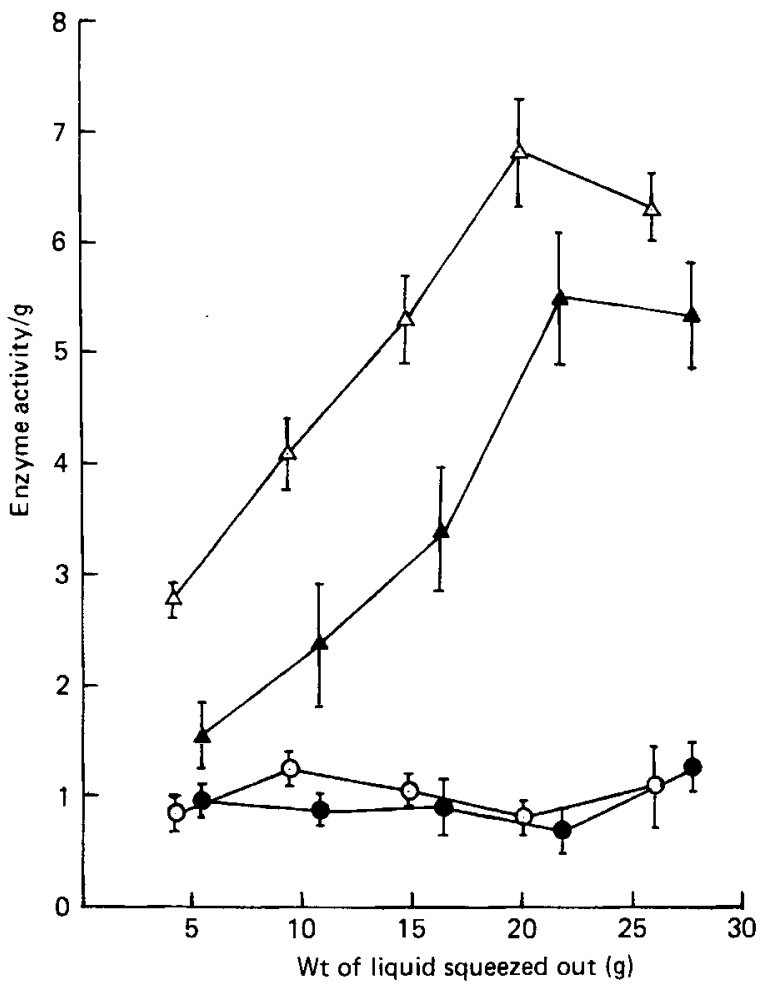

Fig. 4. Expt 3b. Changes in urease and alkaline phosphatase activity in the fractions squeezed out of the bags of solid digesta. The results are means of determinations during control periods and during addition of urea with food. Urease $(0,0)$, alkaline phosphatase $(\Delta, \Delta) ; O, \Delta$, vessel 1 , $\Delta$, vessel 2 .

Table 7. Expt 3. Changes in the specific activity of urease (EC 3.5.1.5) and alkaline phosphatase (EC 3.1.3.1) in the fractions squeezed from the drained solid digesta (compartment 2)

(The alkaline phosphatase results are means for four to five fractions)

\begin{tabular}{|c|c|c|c|}
\hline & \multicolumn{2}{|c|}{ Expt $3 a$} & \multirow{2}{*}{$\begin{array}{l}\text { Expt 3b } \\
\text { Vessel } 2\end{array}$} \\
\hline & Vessel 1 & Vessel 2 & \\
\hline \multicolumn{4}{|c|}{ Urease ( $\mu \mathrm{g}$ ammonia $\mathrm{N} / \mathrm{min}$ per $\mathrm{mg}$ protein) } \\
\hline Urea infusion & $0.36 \rightarrow 0.16$ & $0.47 \rightarrow 0 \cdot 15$ & $0 \cdot 48 \rightarrow 0 \cdot 16$ \\
\hline Addition and controls & $0.11 \rightarrow 0.05$ & $0 \cdot 15 \rightarrow 0.05$ & - \\
\hline \multicolumn{4}{|c|}{ (Exponential decrease with specific rate of $0.05 / \mathrm{g}$ fraction) } \\
\hline \multicolumn{4}{|c|}{ Alkaline phosphatase ( $\mu \mathrm{mol} / \mathrm{h}$ per $\mathrm{mg}$ protein) } \\
\hline Urea infusion & $0.27 \pm 0.02$ & $0.33 \pm 0.02$ & $0 \cdot 15 \pm 0.01$ \\
\hline Addition and controls & $0 \cdot 35 \pm 0 \cdot 01$ & $0.25 \pm 0.01$ & - \\
\hline
\end{tabular}

As mentioned previously, the concentration of ammonia was uniform in compartment 2 and it was consistently much higher than in compartment $1\left(C_{1}\right)$. By measuring the concentration of ammonia in washings and in the washed solid, given the volume of washings and the weight of the washed solid, it was possible to calculate the total content of ammonia in the solid digesta (compartments 2 and 3). Since the volume of liquid in the 
Table 8. Expt 3 a. Specific activities of urease (EC 3.5.1.5) and alkaline phosphatase (EC 3.1.3.1) in compartments 1,2 and 3

(The results are given per unit weight of diaminopimelic acid (DAP, a bacterial marker). The values are means for the two control periods and period of addition of urea in food. The values in parentheses were obtained during the period of infusion of urea $(30$ and $80 \mathrm{mg} / \mathrm{d}$ in Vessels 1 and 2 respectively))

\begin{tabular}{|c|c|c|c|c|c|c|c|c|c|}
\hline & \multirow{3}{*}{$\begin{array}{l}\text { Compartment } \\
\text { no. }\end{array}$} & \multicolumn{4}{|c|}{$\begin{array}{c}\text { Urease } \\
(\mu \mathrm{g} \text { ammonia- } \mathrm{N} / \mathrm{min} \text { per } \mathrm{mg} \mathrm{DAP})\end{array}$} & \multicolumn{4}{|c|}{$\begin{array}{l}\text { Alkaline phosphatase } \\
(\mu \mathrm{mol} / \mathrm{h} \text { per mg DAP })\end{array}$} \\
\hline & & \multicolumn{2}{|c|}{ Vessel 1} & \multicolumn{2}{|c|}{ Vessel 2} & \multicolumn{2}{|c|}{ Vessel 1} & \multicolumn{2}{|c|}{ Vessel 2} \\
\hline & & Mean & $\mathrm{SE}$ & Mean & $\mathbf{S E}$ & Mean & $\mathrm{SE}$ & Mean & $\mathrm{SE}$ \\
\hline Free suspension & 1 & $\begin{array}{c}456 \\
(1043)\end{array}$ & 58 & $\begin{array}{c}441 \\
(1704)\end{array}$ & 45 & $\begin{array}{c}197 \\
(225)\end{array}$ & 8 & $\begin{array}{c}181 \\
(197)\end{array}$ & 10 \\
\hline Washings & 2 & $\begin{array}{c}66 \\
(126)\end{array}$ & 10 & $\begin{array}{c}58 \\
(135)\end{array}$ & 5 & $\begin{array}{c}124 \\
(106)\end{array}$ & 8 & $\begin{array}{c}87 \\
(125)\end{array}$ & 6 \\
\hline Washed solid & 3 & $\begin{array}{c}55 \\
(92)\end{array}$ & 18 & $\begin{array}{c}39 \\
(115)\end{array}$ & 6 & $\begin{array}{c}111 \\
(103)\end{array}$ & 3 & $\begin{array}{c}88 \\
(132)\end{array}$ & 11 \\
\hline
\end{tabular}

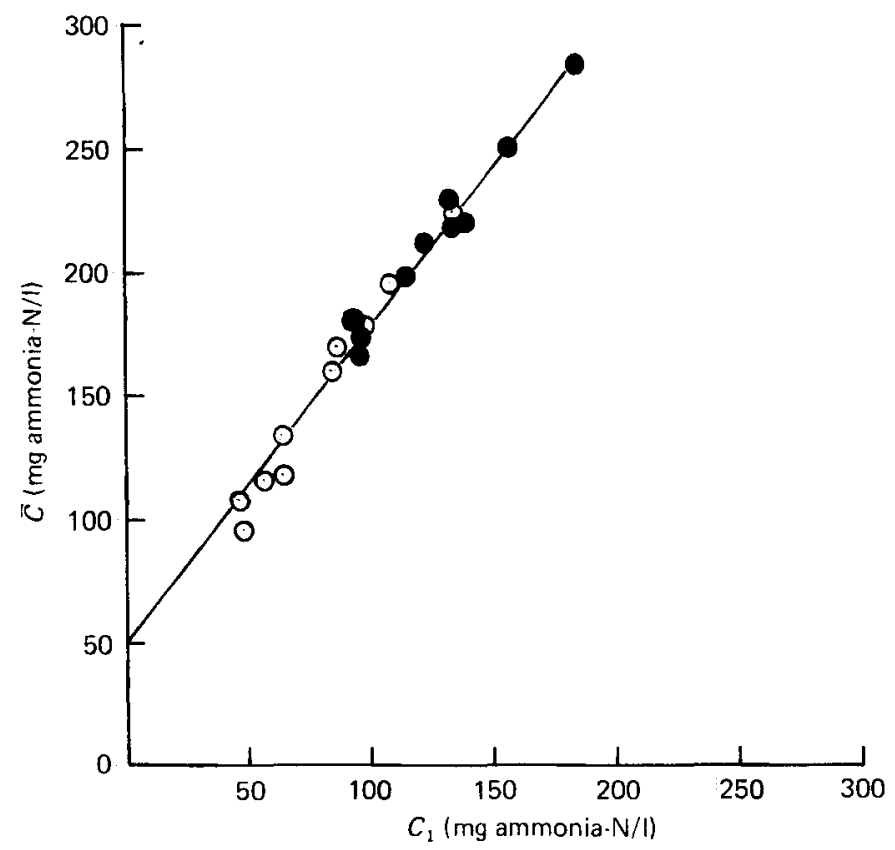

Fig. 5. Relation between the mean concentration of ammonia ( $\mathrm{mg}$ ammonia-N/l) in the solid digesta $(\bar{C})$ and in the strained rumen contents (compartment $1, C_{1}$ ). (O) Vessel 1 (2 parts hay, 1 part barley); (O) vessel 2 (1 part hay, 2 parts barley). The regression equation was $\bar{C}(\mathrm{mg} / 1)=49.8 \pm 1.29 C_{1}, r 0.99$.

digesta is known (Czerkawski \& Breckenridge, 1979b), it is possible to calculate the mean concentration of ammonia in the solid digesta $(\bar{C})$. In all the experiments in this series the mean concentration of ammonia in the solid matrix was considerably higher than in compartment 1. Furthermore there was an acceptable linear relation between $C_{1}$ and $\bar{C}$, as shown by the values from Expt 2 in Fig. 5. Similar relations were obtained in Expts 1 and 3 , but the constants were different $\left(\tilde{C}=88 \cdot 6+1 \cdot 26 C_{1}\right.$ and $\bar{C}=25 \cdot 1+1 \cdot 40 C_{1} \mathrm{mg}$ ammonia-N/l respectively). 
The concentrations of total VFA in compartment 2, like those of ammonia, were generally uniform and they were higher than in compartment 1. For instance, in one experiment the concentration of VFA was $76.9 \pm 2.5$ and $127.7 \pm 6.3 \mathrm{mmol} / 1$ in compartments 1 and 2 respectively (mean for nine results, three treatments in three vessels, each with a different concentrate in the diet).

\section{DISCUSSION}

The development of the model Rusitec system made it possible to study compartmentation but even this simplified system is beset with problems. It is often impracticable or even impossible to devise a comprehensive experiment that would cover all the possibilities; excessive sampling of contents may interfere with the fermentation and the volume of analytical work may be greater than can be managed in a small research unit. Therefore it is better, under certain circumstances, to do several seemingly incomplete experiments than one, very comprehensive experiment, even though such a procedure may lead to certain shortcomings.

The experiments showed that the low urease activity in Rusitec could be 'switched on' by infusion of urea, that the distribution of this activity was different in the three compartments, and that the magnitude of urease activity in Rusitec was a direct function of the rate of input of urea. Not only was there a direct response to increasing input of urea, but the urease activity decreased in a predictable manner when the rates of input were reduced. In agreement with Cook (1976) and Mahadevan et al. (1976) but not with John et al. (1974) and Cheng \& Wallace (1979), the experiments with Rusitec failed to show any inverse relation between the concentration of ammonia and urease activity. The amounts of ammonia in the system simply increased with the input of urea (1.01 and $0.92 \mathrm{mg}$ ammonia- $\mathrm{N} / \mathrm{mg}$ urea- $\mathrm{N}$ with roughage and concentrate diet respectively). It is possible to study the distribution of various substances in compartment 2 and this aspect of the problem was studied in detail.

Because of its importance in the synthesis of microbial protein and undoubtedly because of ease of analysis, the reports on the concentrations of ammonia in the rumen, either as specific work or as part of wider studies, formed a large proportion of literature dealing with rumen studies. In most of the work on $\mathbf{N}$ metabolism in the rumen, little or no regard has been given to the location of the enzyme activities in various parts of the heterogeneous system. In some of the most comprehensive studies of urease activity in the rumen (Cook, 1976; Mahadevan et al. 1976) the sampling was confined to compartment 1 (taken from the rumen by stomach tube). Through the years many attempts were made to determine the optimum concentrations of ammonia in the rumen and to relate it to synthesis of microbial protein (Roffler \& Satter, 1975). Allison (1970) and Satter \& Slyter (1974) arrived at a value of 40-50 mg ammonia-N/1, while Miller (1973) obtained best results with $240 \mathrm{mg}$ ammonia$\mathrm{N} /$ l. Okorie et al. (1977) and Mehrez et al. (1977) obtained maximum efficiency of microbial synthesis with 70 and $200 \mathrm{mg}$ ammonia-N/l respectively. In all these studies, the concentration of ammonia in the rumen meant the concentration in compartment 1 only. Yet, since the concentration of carbohydrate in this compartment is low, it is unlikely to be the most active metabolic site.

The importance of adherent microbial population in the rumen has been recognized (Cheng et al. 1977; Cheng \& Costerton, 1980), and in fact Cheng \& Wallace (1979) suggested that urease production is largely a function of bacteria attached to the sloughed epithelial cells. Since there are no such cells in Rusitec, the source of urease must be different. Crawford et al. (1980) varied the solid retention time and the dilution rate and measured the partition of $\mathrm{N}$ between ammonia, microbial and feed $\mathrm{N}$. Senshu et al. (1980) concluded that the microbial population that can be washed out of the solid digesta 
gives better fermentation results and that it is more representative of the rumen; this is the population of compartment 2. In spite of the voluminous literature on the subject, it is difficult to find reports on the distribution and concentrations of enzymes, substrates and products in the compartments in a properly functioning system.

The space occupied by micro-organisms that cannot be washed out of the solid digesta (compartment 3) is most difficult to study. However, there is no doubt that the function of this compartment is to break down solid food. This compartment has an important role in ruminant nutrition, because this is the site of initial degradation of the most significant component of the diet - the fibre. Compartment 3 must be colonized by micro-organisms at the start of incubation and some of the resulting products must be removed, but not in a haphazard manner. The release of such products directly into compartment 1 , where the microbial population is less dense, might not be the most efficient mechanism. There is a need within the system for a concentrated microbial population that could elaborate the substances produced in compartment 3 , pass other substances from compartment 1 and generally help to provide the trapped population in the inner compartment with nutrients that may be in short supply there. The microbial population of such an intermediate compartment should be in close proximity to the trapped population, but the micro-organisms should not be bound too tightly - a certain amount of movement and migration to the neighbouring regions being desirable. Compartment 2 has been defined in a practical manner (Czerkawski \& Breckenridge, 1979b), it has been termed a shuttle compartment (Czerkawski, 1979) and it has many of the desirable properties that have been discussed previously.

The determinations of the concentration profiles of a limited number of substances in compartment 2 showed that they could be divided into two main groups. The concentrations of some substances increased steadily with the depth of compartment 2 (protein, DNA, alkaline phosphatase and some other enzymes) while, apart from a small boundary region close to compartment 1, the concentration of other substances appeared to be constant (ammonia, VFA, urease).

Alkaline phosphatase activity is concerned with reactions within the cells and therefore it is not surprising that there is a close relation between this enzyme and cellular material (protein, DNA). This gives a constant specific enzyme activity and one must conclude that this part of microbial population of compartment 2 has a uniform composition and that there is simply a marked increase in population density as we go from compartment 1 to 3. If the specific enzyme activity increases under these conditions (e.g. some glycosidases), then we must conclude that the population is oriented towards compartment 3 and may, in due course, become part of that compartment.

The specific urease activity decreased with the 'depth' of compartment 2 and it was considerably greater in compartment 1 than in 2 . This would suggest that the origin of urease activity is in compartment 1 and that the activity in compartment 2 is simply due to decreasing penetration from that region. Yet, this may not be a proper explanation. A simple penetration of ureolytic population from compartment 1 would not necessarily produce a uniform ureolytic activity in compartment 2 and it is unlikely that this activity would be much higher than in compartment 1 . On the other hand, a high and uniform urease in compartment 2 compared with lower activity in compartment 1 may help to maintain a flow of urea from compartment 1 to 2 . An over-efficient hydrolysis of urea in compartment 1 may lead to loss of ammonia with effluent liquid and absorption through the rumen wall. Since the concentration of ammonia was always greater in compartment 2 than in compartment 1 , one would expect no net flow of this substance from compartment 1 to 2. The maintenance of high and uniform concentration of ammonia in compartment 2 appears to be a desirable characteristic of the system since it may control the supply of $\mathrm{N}$ to the inner fibre-digesting population of micro-organism. 
Expts $3 \mathrm{a}$ and $3 \mathrm{~b}$ showed the dramatic effect of the mode of administration of urea on the magnitude of urease activity. During infusion of urea its concentration was low and yet urease activity increased dramatically. The concentration of urea in compartment 1 was very high at least for 3-4 h after addition of this compound to the vessel, yet there was little or no increase in urease activity. This was not due to repression by high concentrations of urea because in Expt $3 \mathrm{~b}$ a combined addition and infusion of urea resulted in a normal increase in enzyme activity. During infusion of urea, its concentrations were not significantly different from controls, yet it cannot be argued that the changes in urease activity were independent of the concentrations of urea because the enzyme activity was directly related to the concentration of urea in the infused buffer solution.

There is evidence that another enzyme, glutamine synthatase, can regulate the production of urease in Selenomonas ruminantium (Smith \& Bryant, 1979) and the activities of both these enzymes could be increased many-fold when ammonia was limiting. The urease activity was highly repressed with 3-20 mM ammonia. In the present experiments the infusion of urea increased urease activity although the concentration of ammonia was within the range 4-21 mM. Smith \& Bryant (1979) showed also that histidine seemed to repress urease without changing glutamine synthatase in the micro-organism.

In conclusion, the work reported here shows a novel approach to the study of a complex multi-compartment ecosystem, but the results should be considered to be only the beginning. It will be necessary to do much work in vitro and in vivo before the value of this approach is fully realized.

The authors are grateful to Mrs C. Faulds for expert and extensive analytical support.

\section{REFERENCES}

Allison, M. J. (1970). In Physiology of Digestion and Metabolism in the Ruminant, p. 456 [A. T. Phillipson, editor]. Newcastle-upon-Tyne: Oriel Press.

Brent, B. E., Adepoju, A. \& Portela, F. (1971). J. Anim. Sci. 32, 794.

Brice, R. E. \& Morrison, I. M. (1981). Proc. Nut. Soc. 40, 75A.

Burton, K. (1955). Biochem. J. 62, 315.

Chalupa, W. (1968). J. Anim. Sci. 27, 207.

Chalupa, W. (1972). Fedn Proc. Fedn Am. Socs exp. Biol. 31, 1152.

Chalupa, W., Clark, J., Opliger, P. \& Lavker, R. (1970). J. Nutr. 100, 161.

Cheng, K.-J., Akin, D. E. \& Costerton, J. W. (1977). Fedn Proc. Fedn Am. Socs exp. Biol. $36,193$.

Cheng, K.-J. \& Costerton, J. W. (1977). Appl. Environ. Microbiol. 34, 586.

Cheng, K.-J. \& Costerton, J. W. (1980). In Digestive Physiology and Metabolism in Ruminants, p. 227

[Y. Ruckebusch and P. Thivend, editor]. Lancaster; MTP Press Limited.

Cheng, K.-J., Hironaka, R. \& Costerton, J. W. (1976). Can. J. Microbiol. 22, 764.

Cheng, K.-J. \& Wallace R. J. (1979). Br. J. Nutr. 42, 553.

Cook, A. R. (1976). J. gen. Microbiol. 92, 32.

Crawford, R. J., Hoover, W. H. \& Junkins, L. L. (1980). J. Anim. Sci. 51, 986.

Czerkawski, J. W. (1974). J. Sci. Fd Agric. 25, 45.

Czerkawski, J. W. (1976). Br. J. Nutr. 36, 311.

Czerkawski, J. W. (1979). The Hannah Res. Inst. Report p. 69.

Czerkawski, J. W. \& Breckenridge, G. (1977). Br. J. Nutr. 38, 371.

Czerkawski, J. W. \& Breckenridge, G. (1979a). Br. J. Nutr. 42, 217.

Czerkawski, J. W. \& Breckenridge, G. (1979 b). Br. J. Nutr. 42, 229.

Czerkawski, J. W., Christie, W. W., Breckenridge, G. \& Hunter, M. L. (1975). Br. J. Nutr. $34,25$.

Czerkawski, J. W. \& Clapperton, J. L. (1968). Lab. Pract. 17, 994.

Dinsdale, D., Cheng, K.-J., Wallace, R. J. \& Goodlad, R. A. (1980). Appl. Environ. Microbiol. 39, 1059.

Erfle, J. D., Sauer, F. D. \& Mahadevan, S. (1977). J. Dairy Sci. 60, 1064.

Houpt, T. R. (1970). In Physiology of Digestion and Metabolism in the Ruminant, p. 119 [A. R. Phillipson, editor]. Newcastle-upon-Tyne: Oriel Press.

John, A., Isaacson, H. R. \& Bryant, M. P. (1974). J. Dairy Sci. 57, 1003.

Jones, G. A. (1967). In Urea as a Protein Supplement, p. 111 [M. H. Briggs, editor]. Oxford: Pergamon Press Ltd. Kennedy, P. M. (1980). Br. J. Nutr. 43, 125. 
Kennedy, P. M. \& Milligan, L. P. (1980). Can. J. Anim. Sci. 60, 205.

Mahadevan, S., Sauer, F. \& Erfle, J. D. (1976). J. Anim. Sci. 42, 745.

Marty, R. J. \& Demeyer, D. I. (1973). Br. J. Nutr. 30, 369.

Mehrez, A. Z., Ørskov, E. R. \& McDonald, I. (1977). Br. J. Nutr. 38, 437.

Miller, E. L. (1973). Proc. Nutr. Soc. 32, 79.

Obara, Y.\& Shimbayashi, K. (1979). Br. J. Nutr. 42, 497.

Okorie, A. U., Buttery, P. J. \& Lewis, D. (1977). Proc. Nut. Soc. 36, 39 A.

Pearson, R. M. \& Smith, J. A. B. (1943). Biochem. J. 37, 148.

Rahman, A. S. \& Decker, P. (1966). Nature, Lond. 209, 618.

Roffler, R. E. \& Satter, L. D. (1975). J. Dairy Sci. 58, 1880.

Satter, L. D. \& Slyter, L. L. (1974). Br. J. Nutr. 32, 199.

Senshu, T., Nakamura, K., Sawa, A., Miura, H. \& Matsumoto, T. (1980). J. Dairy Sci. 63, 305.

Sigma Chemical Co. (1980a). Technical Bulletin 104. St Louis, USA: Sigma Chemical Co.

Sigma Chemical Co. $(1980 b)$. Technical Bulletin 535. St Louis, USA: Sigma Chemical Co.

Slyter, L. L., Oltjen, R. R., Kern, D. L. \& Weaver, J. M. (1968). J. Nutr. 94, 185.

Smith, F. (1965). Meth. Biochem. Analysis 3, 180.

Smith, M. S. \& Bryant, M. P. (1979). Am. J. clin. Nutr. 32, 149.

Stanier, G. \& Davies, A. (1981). Br. J. Nutr. 45, 567.

Stern, M. D. \& Hoover, W. H. (1979). J. Anim. Sci. 49, 1590.

Tillman, A. D. \& Sidhu, K. S. (1968). J. Anim. Sci. 28, 689.

Toennies, G. \& Feng, F. (1965). Analyt. Biochem. 11, 411.

Wallace, R. J. (1979). J. Appl. Bacteriol. 47, 443.

Wallace, R. J., Czerkawski, J. W. \& Breckenridge, G. (1981). Br. J. Nutr. 46, 131. 